\section{Legislation and policy for adolescent health in Latin America and the Caribbean ${ }^{1}$}

1 Based on: Rodriguez-Garcia R, Russell JS. Legislative and policy environment for adolescent health in Latin America and the Caribbean. Washington, D.C.: Pan American Health Organization, Division of Health Promotion and Protection, Program of Adolescent Health; 1997.
In Latin America and the Caribbean, adolescentspersons between the ages of 10 and 19-now comprise $21 \%$ of the total population, or more than 100 million individuals. And while mortality rates among those adolescents are low in comparison with other age groups, there is much that can and should be done to lower death rates and improve health among those young people.

Among adolescents in Latin America and the Caribbean, more deaths result from external causes-including accidents, homicides, and suicides-than from infectious diseases, circulatory diseases, and cancer combined. Vehicular deaths are the most common cause of accidental death, and the number has risen as the use of motor vehicles has become more common. Violence is also a growing problem. In the Region of the Americas, more than a quarter of the deaths due to homicide occur among adolescents. Many young people must also deal with other forms of violence, including neglect and sexual and emotional abuse (1).

Other adolescent health problems come from the use of alcohol, drugs, and tobacco, as well as poor nutrition and lack of physical activity. High levels of early and unprotected sexual activity lead to infection with HIV and other sexually transmitted diseases, unintended pregnancies, and early motherhood. Worsening that situation are the difficulties that adolescents have in accessing reproductive health services in many countries of Latin America and the Caribbean.

In response to those adolescent health concerns, the Pan American Health Organization (PAHO) has been working with a variety of partners and on a wide range of activities. For example, in 1995 the Andean Parliament asked for help from PAHO in drafting a law to promote adolescent health and development. As part of that work, more than 100 laws and regulations from Latin America and the Caribbean were reviewed. The following year representatives from many countries of Latin America and the Caribbean assembled for a meeting on adolescent health and again emphasized the need for technical assistance on legislative and policy analysis relating to adolescent health.

To help address that need, a team was assembled that included specialists from PAHO, the George Washington University Center for International Health, and the U.S. Department of Health and Human Services. Overall goals for the work included developing a conceptual framework for adolescent health and human development, build- 
ing an analytical model, and analyzing specific laws and national policies that refer to adolescent health.

Applying a conceptual framework linking health and development (2), the study group reviewed published documents and technical materials, interviewed key informants, and examined national legislation and policies passed between April 1976 and August 1996. A questionnaire sent to PAHO country representatives collected information on the rights, obligations, and legal ages for young people for marriage, driving, smoking, drinking alcohol, mandatory education, voting, military service, and access to reproductive health services (Table 1). Another questionnaire, sent to all the PAHO country offices, sought information on national policies on adolescent health being implemented by the Ministry of Health in those nations.

In total, 191 existing laws and regulations from 16 countries were analyzed, as well as adolescent health policies from eight nations. The research found a positive and dynamic environment for adolescent health concerns in many countries, often involving not only the health sector, but also other sectors such as education, labor, justice, and commerce and industry (Table 2). However, in the analysis of rights and legal ages, the investigation found that youth in some countries may face significant barriers in accessing reproductive health services.

Besides producing data on the legislative and policy environment for adolescent health, the research led to an overall framework and model that can be used to analyze the current situation in a country, as well as to guide the development of new policies and laws. With this information and these tools, local leaders can learn from experiences elsewhere, produce more appropriate laws and policies in their own countries, and improve the quality of health and other social services for adolescents.

Another tool that resulted from the work was a model "advocacy fact sheet." Just two pages long, the sheet is intended to provide country-specific facts on the status of adolescent health, explain the importance of youth health promotion, and identify the most important health needs of young people, as well as the actions and sectoral commitments needed to advance the health and development of adolescents.

Adolescent health is best dealt with in a comprehensive, holistic manner. Based on the analysis of the existing laws and policies, an appropriate adolescent health policy should be addressed through all of the following sectors:

Health. Laws and policies on youth health should encourage health promotion and positive behaviors and also eliminate barriers to accessing such health services as family planning, contraception, treatment of sexually transmitted diseases, and other reproductive health needs. To maximize that access, services need to be "youth friendly" and should be integrated and comprehensive at the local level. Capacity building can increase the skills of professionals who work with youth.

TABLE 1. Youth rights and legal ages in selected countries of Latin America and the Caribbean, 1996

\begin{tabular}{|c|c|c|c|c|c|c|c|c|c|c|c|c|c|c|}
\hline \multirow[b]{2}{*}{ Right/Age } & \multicolumn{14}{|c|}{ Country $^{\mathrm{a}}$} \\
\hline & ARG & $\mathrm{BOL}$ & BRA & $\mathrm{CHI}$ & $\mathrm{COL}$ & DOR & JAM & MEX & $\mathrm{NIC}$ & PER & TRT & USA & URU & VEN \\
\hline \multicolumn{15}{|l|}{ Upper age for } \\
\hline adolescence & 19 & 19 & 19 & 19 & 19 & & 19 & 18 & 19 & 19 & 21 & 19 & 18 & 19 \\
\hline Upper age for youth & 24 & 24 & 24 & 30 & 24 & & 24 & 24 & 24 & 24 & 25 & 24 & 20 & 24 \\
\hline Minimum voting age & 21 & 18 & 16 & 18 & 16 & & 18 & 18 & 16 & 18 & 18 & 18 & 18 & 18 \\
\hline Minimum driving age & 17 & 18 & 18 & 18 & & 16 & 18 & 18 & 18 & 18 & & 16 & 18 & 18 \\
\hline Minimum age to work & $N A^{b}$ & 18 & NA & NA & 18 & 18 & NA & 18 & NA & NA & 18 & 21 & 18 & 18 \\
\hline \multicolumn{15}{|l|}{$\begin{array}{l}\text { Minimum age for } \\
\text { females to be }\end{array}$} \\
\hline married & 14 & 18 & 16 & 18 & 18 & 16 & 16 & 18 & & 18 & 18 & 16 & 18 & 18 \\
\hline \multicolumn{15}{|l|}{ Mandatory schooling } \\
\hline $\begin{array}{l}\text { Obligatory military } \\
\text { service (age) }\end{array}$ & No & $\begin{array}{l}\text { Yes } \\
(18)\end{array}$ & $\begin{array}{l}\text { Yes } \\
(18)\end{array}$ & $\begin{array}{l}\text { Yes } \\
(18)\end{array}$ & $\begin{array}{l}\text { Yes } \\
(18)\end{array}$ & No & No & $\begin{array}{l}\text { Yes } \\
(18)\end{array}$ & No & $\begin{array}{l}\text { Yes } \\
(18)\end{array}$ & No & No & No & \\
\hline $\begin{array}{l}\text { Age to hold political } \\
\text { office } \\
\text { Age allowed to testify in }\end{array}$ & 21 & 18 & 18 & 21 & & & & 18 & & 25 & & 25 & 25 & \\
\hline court & 18 & 18 & 18 & & & & & 18 & & & 18 & Any age & 18 & 18 \\
\hline $\begin{array}{l}\text { Minimum age to give } \\
\text { medical consent }\end{array}$ & 21 & & 18 & & & & 18 & & & 18 & & 18 & 18 & \\
\hline $\begin{array}{l}\text { IVIIIImum age to recelve } \\
\text { reproductive services }\end{array}$ & 21 & 18 & 18 & & & & 18 & & & & & 18 & & \\
\hline
\end{tabular}

${ }^{\mathrm{a}} \mathrm{ARG}=$ Argentina; $\mathrm{BOL}=$ Bolivia; $\mathrm{BRA}=$ Brazil; $\mathrm{CHI}=$ Chile COL = Colombia; $\mathrm{DOR}=$ Dominican Republic; JAM = Jamaica; $\mathrm{MEX}=\mathrm{Mexico} ; \mathrm{NIC}=\mathrm{Nicaragua} ;$ PER $=$ Peru; TRT $=$ Trinidad and Tobago; USA = United States; URU = Uruguay; VEN = Venezuela.

${ }^{b} \mathrm{NA}=$ Not applicable. 
TABLE 2. Number of laws and regulations analyzed and the sectors which address youth health in selected countries of Latin America and the Caribbean, 1996

\begin{tabular}{|c|c|c|c|c|c|c|c|c|c|}
\hline & \multirow{2}{*}{$\begin{array}{l}\text { No. of laws and } \\
\text { regulations } \\
\text { analyzed }\end{array}$} & \multirow{2}{*}{$\begin{array}{l}\text { No. of sectors } \\
\text { involved in youth } \\
\text { health }\end{array}$} & \multicolumn{7}{|c|}{ Sector ${ }^{a}$} \\
\hline & & & EDUC & LABR & HLTH & ECON & JUST & COMM & CULT \\
\hline Argentina & 23 & 4 & $\mathrm{X}$ & $x$ & $\mathrm{X}$ & & & & \\
\hline Bolivia & 4 & 1 & & $x$ & & & & & \\
\hline Brazil & 19 & 3 & $\mathrm{X}$ & $X$ & $x$ & & & & \\
\hline Chile & 20 & 4 & $\mathrm{x}$ & $x$ & $\mathrm{x}$ & & $x$ & & \\
\hline Colombia & 17 & 4 & & $x$ & $\mathrm{x}$ & & $x$ & $\mathrm{X}$ & \\
\hline Costa Rica & 12 & 4 & $x$ & $x$ & $x$ & & & $x$ & \\
\hline Cuba & 17 & 4 & $x$ & $x$ & $x$ & & & & $x$ \\
\hline Ecuador & 20 & 3 & $\mathrm{X}$ & $x$ & $x$ & & & $x$ & \\
\hline El Salvador & 10 & 1 & & $x$ & & & & & \\
\hline Guatemala & 8 & 2 & & $x$ & $x$ & & & & \\
\hline Mexico & 5 & 2 & & $x$ & $x$ & & & & \\
\hline Peru & 10 & 3 & & $x$ & $X$ & & & $\mathrm{X}$ & \\
\hline Uruguay & 7 & 3 & & $x$ & $x$ & & & $x$ & \\
\hline Venezuela & 9 & 1 & $x$ & & & & & & \\
\hline
\end{tabular}

${ }^{a}$ EDUC = Education; LABR = Labor; HLTH = Health; ECON = Economic; JUST = Justice; COMM = Commerce/industry; CULT = Culture/national affairs.

Education. Laws and policies should encourage both formal and informal education and vocational training, for both young men and young women. The school curriculum should include components on nutrition, hygiene, wellness, HIV / AIDS, reproductive health, substance abuse prevention, transit safety, and physical fitness.

Economic/Labor and Social Security. There should be minimum ages set for minors to work, as well as restrictions on their working in unhealthy environments.

Commerce and Industry. Comprehensive laws should restrict the sale to youth of such products as tobacco and alcohol.

Justice. The justice sector should encourage compliance with legislation to protect youth. One key area is vehicular safety, such as by enforcing laws relating to drugs and alcohol, seat-belt use, and driving age.

\section{SINOPSIS}

\section{Leyes y políticas en torno a la salud de los adolescentes en América Latina y el Caribe}

La tasa de mortalidad de los adolescentes es menor que la de cualquier otro grupo de edad en América Latina y el Caribe.
No obstante, varios factores ponen en peligro la salud y el desarrollo de los jóvenes. La Organización Panamericana de la Salud (OPS), en su esfuerzo por responder a los problemas de salud de los adolescentes, ha hecho una contribución al haber analizado el contexto legislativo y politico en que se manejan dichos problemas.

Un grupo compuesto de expertos de la OPS, del Centro de Salud Internacional de la Universidad George Washington y del Departamento de Salud y Servicios Humanos de los Estados Unidos investigó y examinó las leyes y políticas nacionales en relación con la salud de los adolescentes y recogió información sobre las edades en que los jóvenes pueden legalmente ejercer ciertos derechos, como el de casarse, manejar, fumar, consumir bebidas alcohólicas, recibir educación obligatoria, votar, prestar servicio militar y tener acceso a servicios de salud reproductiva. La búsqueda reveló un contexto favorable y dinámico en torno a la salud de los adolescentes en muchos países, a menudo con la participación de varios sectores. La investigación mostró, sin embargo, que es posible que en algunos países los jóvenes enfrenten barreras importantes que obstaculizan su acceso a los servicios de salud reproductiva. La búsqueda también dio origen a un marco y modelo analítico que puede servir para analizar la situación actual dentro de un país determinado y orientar la formulación de nuevas políticas y leyes al respecto.

\section{REFERENCES}

1. Pan American Health Organization. Health in the Americas, 1998 edition. Washington, D.C.: $\mathrm{PAHO} ; 1998$.
2. Rodriguez-Garcia R, Goldman A, eds. The health-development link. Washington, D.C.: Pan American Health Organization; 1994. 